Kalpa Publications in Civil Engineering
Volume 1, 2017, Pages 132-136
ICRISET2017. International Conference on Re-
search and Innovations in Science, Engineering
\&Technology. Selected papers in Civil Engineering $\quad$ Ka L po

\title{
Adaptive Pushover Analysis of Irregular RC Moment Resisting Frames
}

\author{
Rutvik K. Sheth ${ }^{\mathrm{a}}$, Dr. Devesh P. Soni ${ }^{\mathrm{b}}$, Minoli D. Shah ${ }^{\mathrm{c}}$ \\ ${ }^{a}$ Assistant Professor, Dharmsinh Desai University, Nadiad-387001, Gujarat \\ Email: rutviksheth123@gmail.com, (M)+919428658643 \\ ${ }^{b}$ Professor, Sardar Vallabhbhai Patel Institute of Technology, Vasad-388306, Gujarat \\ Email:devesh18@gmail.com, \\ ${ }^{c}$ M.Tech Student, Dharmsinh Desai University, Nadiad-387001, Gujarat \\ Email: minolishah1307@gmail.com
}

\begin{abstract}
Researchers and engineers certainly prefer to use nonlinear static methods over complicated nonlinear time-history methods. However, in nonlinear static procedure both predetermined target displacement and force distribution pattern are based on a false assumption that the structural behavior and its responses are dominated by the fundamental vibration modes. Therefore, over the past decades, there have been a great number of studies on considering higher mode contribution in nonlinear static results. The Displacement-based Adaptive Pushover Analysis (DAP) is one of the performance assessments tool for improving the accuracy of the obtained results of nonlinear static analysis in estimating the seismic demands of the structures. In this paper, 5 storey Lshaped RC frame is analyzed for seismic Zone IV and designed as per provisions of IS codes. Performance evaluation is carried out by nonlinear static analysis as well as adaptive pushover analysis and results are compared.
\end{abstract}

\section{Introduction}

Elastic analysis gives a good indication of the elastic capacity of the overall structure and indicates where first yielding occurs. It can't predict failure mechanisms and account for redistribution of forces

C.D. Modhera, G.J. Joshi, D. Soni, I.N. Patel, A.K. Verma, L.B. Zala, S.D. Dhiman, D.R. Bhatt, J.M. Rathod, B.C. Goradiya, M.S. Holia and D.K. Patel (eds.), ICRISET2017 (Kalpa Publications in Civil Engineering, vol. 1), pp. 132-136 
during progressive yielding. In performance based design response of structure is considered beyond elastic limit. Inelastic analysis procedures help to understand that how the building really works by identifying modes of failure \& the potential of progressive collapse. Static non-linear analysis is one of the analysis technique used for performance based design. Pushover or capacity based analysis is more popular as a static nonlinear analysis.

\section{Performance Based Seismic Evaluation}

Building codes require that structures should be designed to withstand a certain intensity of ground acceleration, with the intensity of the ground motion depending on the seismic hazard. Because of the high forces imparted to the structure by the earthquake, the structures are usually designed to have some yielding. The goal of earthquake engineering is to minimize loss of life due to the collapse of the yielding structure. However, the costs involved in replacing and rehabilitating structures damaged by the relatively moderate earthquakes have proven that the "Life-Safe" building design approaches are economically inefficient. As a result, the principle of "Performance Based Earthquake Engineering" (PBEE), which promotes the idea of designing structures with higher levels of performance standards across multiple limit states, has been proposed.

The performance evaluation technique is used to evaluate the performance of the structure during the particular seismic activity. It is used for design verification for new construction, evaluation of existing structures to know the damage states and correlation of damage states of structures to various amplitudes of the ground motion. The procedure compares the capacity of the structure with the demands of the structure. Performance-based design has many different interpretations, and according to Applied Technology Council ATC 40 document, performance-based design refers to the methodology in which structural criteria are expressed in terms of achieving a performance objective.

\section{Nonlinear Adaptive Pushover Analysis Procedure}

Antoniou and Pinho have proposed a displacement-based adaptive pushover analysis (DAP) in 2004 to take into account the updated loading vector at each analysis step according to current dynamic characteristics of the building. The aim of adaptive pushover analysis is to evaluate the seismic performance of the structure by predicting seismic demands and capacity of a building and considering its dynamic response characteristics includes the effect of the frequency content and deformation of input motion. (Pinho \& Antoniou, 2004).

The lateral load distribution in the adaptive pushover method, continuously updated during the analysis, depending to modal shapes and participation factors obtained by performing eigenvalue analysis at each step of analysis. DAP is fully multi-modal method that take into account the modification of the inertia forces, the structural stiffness softening, and its period elongation due to spectral amplification (Antoniou \& Pinho, 2004).

DAP has the capability to update and change the horizontal load distributions based on the constantly changing modal properties of the structure. This solves the drawback of fixed-load pattern of the pushover analysis, providing a more accurate tool for assessing structural performance and better response estimator than conventional pushover methods. This is particularly important, in structures that the effects of higher modes play a major role in its dynamic structural response. 
The Force-Based, as well as the Displacement-Based Pushover procedures have been implemented by Antoniou and Pinho in SeismoStruct (Seismosoft, 2005), a fibre-modeling Finite Element program for seismic analysis of framed structures. The implementation of the proposed algorithm can be structured in four main stages: (i) definition of nominal load vector and inertia mass, (ii) computation of load factor, (iii) calculation of normalized scaling vector (iv) update of loading displacement vector. The Displacement- and the Force-Based approaches are essentially equivalent, and they differ only in the steps (iii) and (iv).

\section{Evaluation of RC Frame using Static and Adaptive Pushover Analysis}

The present paper focuses on the verification of the increased accuracy potential of displacementbased adaptive pushover method to estimate the response characteristics of RC buildings subjected to earthquake excitation. DAP and conventional pushover analyses are therefore carried out and compared in terms of both global and local response. Five-storey L shape RC moment resisting frame with typical storey heights of $3.50 \mathrm{~m}$ and ground storey height of $4.50 \mathrm{~m}$ is considered for the study. It was located in Zone-IV and constructed on firm soil condition. Geometry of the frame is shown in Figure 1.

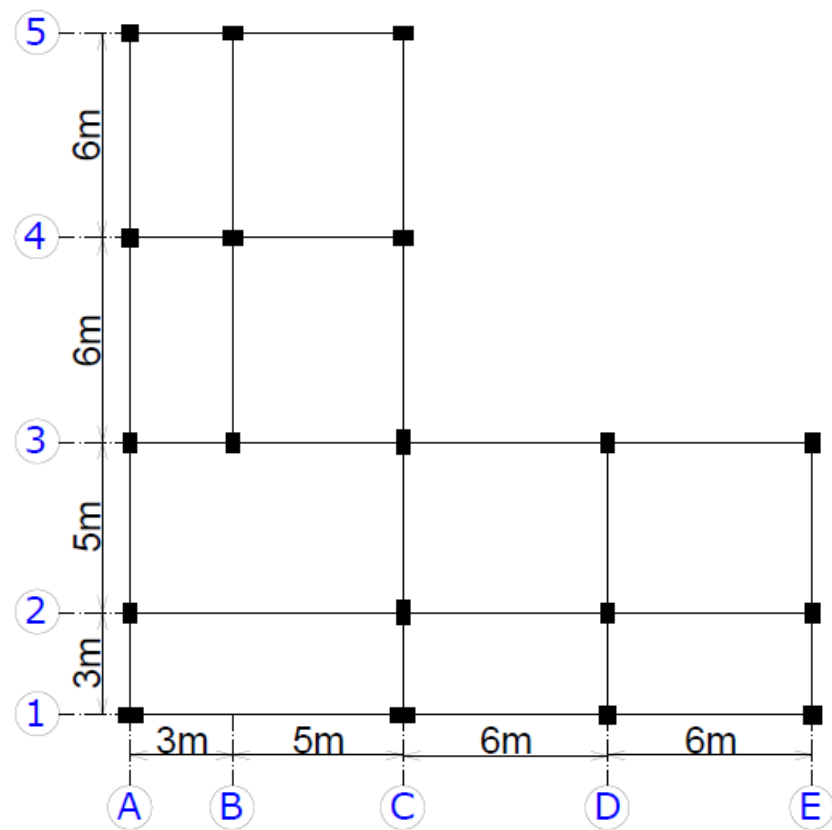

Figure 1. Plan of L-Shape Frame

Response Reduction factor of 5 was used for design of special RC moment-frame. The loading considered was self-weight of beams, columns and slabs, floor finish and live load on slabs. The frame was then designed for load combination (a) 1.5(DL+IL) (b) 1.2(DL+IL \pm EL) (c) 1.5(DL \pm EL) as per IS Code. The design acceleration and displacement spectrum were used, which corresponds to IS 
1893 (Part 1): 2002 for firm soil for 5\% damping. The percentage of steel for columns ranges from $1 \%$ to $2.50 \%$.

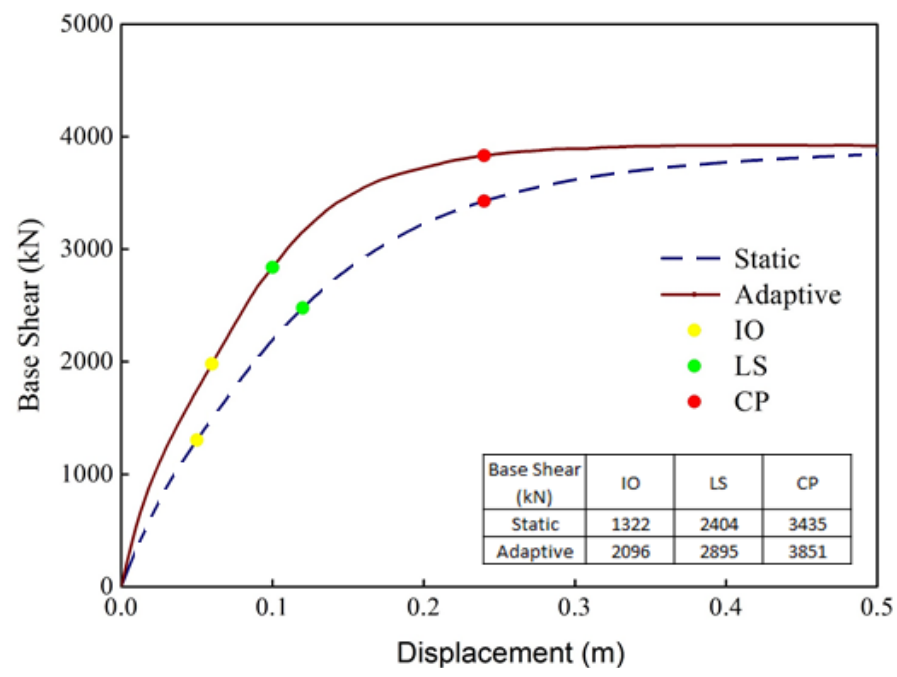

Figure 2. Capacity Curve for 5 Storey Frame

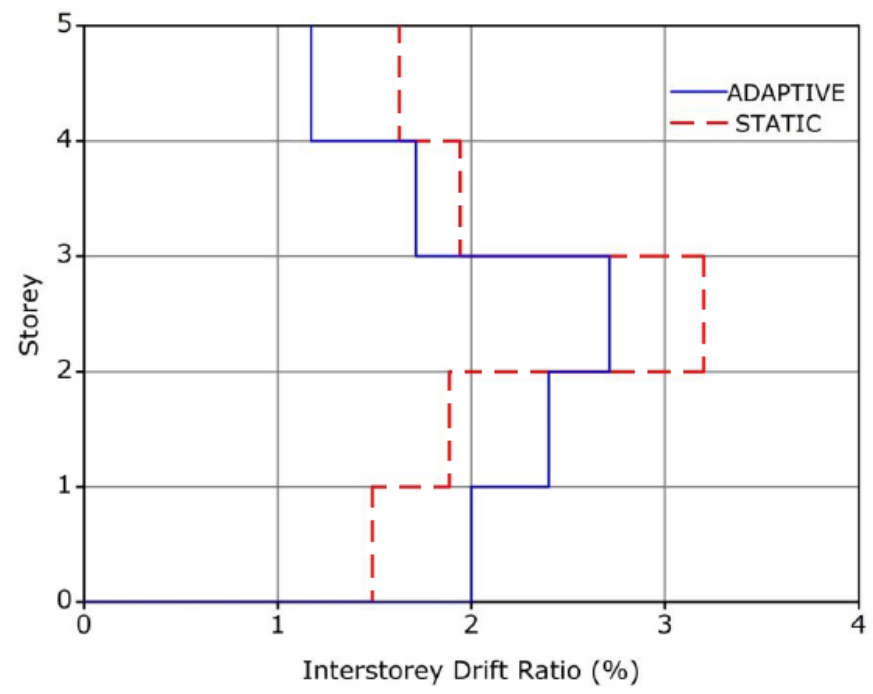

Figure 3. Interstorey Drift Ratio Profile for 5 Storey Frame

The performance evaluation of frame is done using SeismoStruct software upto 3\% target drift limit. The capacity curve for static pushover and adaptive pushover analysis is shown in Figure 2 . The adaptive pushover analysis shows higher capacity compared to static pushover analysis. The interstorey drift ratio profile for $2 \%$ total target drift are shown in Figure 3. The maximum interstorey drift value observed in adaptive pushover analysis is $2.75 \%$ and static pushover analysis is $3.23 \%$. 


\section{Conclusion}

The main objective of the present paper was to use Displacement-based Adaptive Pushover for Performance evaluation and show the effectiveness of the method over conventional Pushover Analysis. Nonlinear static procedures represent in the current design practice, an easier and thus appealing alternative with respect to nonlinear dynamic analysis and overcome the major drawbacks in time-history analysis. Five storey L-shape RC moment resisting frame is evaluated using both procedures and results are compared in terms of pushover curve and interstorey drift ratio profile. It is observed from the results that pushover analysis shows less capacity and higher interstorey drift ratio compared to adaptive pushover analysis. The performance limit states Immediate Occupancy, Life Safety and Collapse Prevention are reached at base shear of $1304 \mathrm{kN}, 2477 \mathrm{kN}$ and $3427 \mathrm{kN}$ respectively for conventional pushover analysis and at base shear of $1980 \mathrm{kN}, 2838 \mathrm{kN}$ and $3832 \mathrm{kN}$ for DAP analysis. The better performance of DAP analysis procedure can be attributed to the consideration of higher mode effects, lateral load continuously updated at each step as compared to conventional pushover analysis.

\section{References}

Antoniou, S. and Pinho, R. (2004), "Development and verification of a displacement based Adaptive Pushover procedure", Journal of Earthquake Engineering, 8(5), 643-661.

Abbasnia, R. and Davoudi, A. T (2014), “An Improved Displacement-Based Adaptive Pushover procedure for the Analysis of Frame Buildings", Journal of Earthquake Engineering, 18, 987-1008.

Chopra, A. K. and Goel, R. K. (2001), “A Modal Pushover Analysis Procedure to Estimate Seismic Demands for Buildings - Theory and Preliminary Evaluation", Pacific Earthquake Engineering Research Center

Ghobarah, A., (2001), "Performance-based design in earthquake engineering: state of Development", Engineering Structures, 23, 878-884.

IS 1893 (Part 1): 2002, Criteria for Earthquake Resistant Design of Structures, Part-1 General Provisions and Buildings (Fifth Revision), Bureau of Indian standard, New Delhi.

IS 456:2000, Plain and Reinforced code of practice (Fourth Revision), Bureau of Indian standard, New Delhi.

Kim, S. P. and Kurama, Y. C. (2008), "An alternative pushover analysis procedure to estimate seismic displacement demands", Engineering Structures, 30, 3793-3807.

Pillai, U. and Menon D. (2003), 'Reinforced Concrete Design', Second edition, Tata McGraw - Hill.

Varughese, J.A. and Menon, D. (2012), "Criteria for performance evaluation of RC building frames using non-linear time history analysis for performance-based design”, International Conference on Structural Engineering Construction and Management, Kandy. 